\title{
Control Methods on Three-phase Power Converters in Photovoltaic Systems
}

\author{
Othmane Salama $^{1}$, Abdelmoumen Tabyaoui ${ }^{2}$, Mohamed Benchagra ${ }^{3}$ \\ ${ }^{1,2}$ University Hassan1, LRMI Laboratory, FST Settat, Morocco \\ ${ }^{3}$ University Hassan1, LISERT Laboratory, ENSA Khouribga, Morocco
}

\begin{tabular}{l}
\hline Article Info \\
\hline Article history: \\
Received Sep 2, 2018 \\
Revised Sep 11, 2018 \\
Accepted Sep 25, 2018 \\
\hline Keyword: \\
Harmonic distortion \\
MPPT \\
Multilevel inverter \\
Nonlinear control \\
Photovoltaic
\end{tabular}

\begin{abstract}
In this paper, a three-phase load connected to a NPC three-level inverter is presented. To generate gate signals for the multilevel inverter, two commands are developed and compared: the phase disposition pulse width modulation (PDPWM) and the space vector pulse width modulation (SVPWM). DC supply is provided by photovoltaic cells. Boost converter controls the power transfer from photovoltaic generator. Due to nonlinear I-V characteristics of photovoltaic cells, a maximum power point tracking algorithm is adopted to maximize the output power, the nonlinear controller (sliding mode) is developed and simulated. To verify the effectivnesse of the introduced controller, it is compared with the fuzzy logic controller. Matlabsimulink is used for simulation, analysis and interpretation the results of these controllers
\end{abstract}

Copyright $@ 2018$ Institute of Advanced Engineering and Science. All rights reserved.

\section{Corresponding Author:}

O. Salama,

LRMI Laboratory, University Hassan1,

Faculty of Sciences and Technology BP 577, 26000, Settat, Morocco.

Email: o.salama@uhp.ac.ma

\section{INTRODUCTION}

Solar energy is a valuable alternative to the energy from fossil fuels. The PV energy is developing very rapidly, it is durable and without polluting the environment. For controlling, the delivered electric power it is anticipated an action on electronic power interface connecting the PV generator with its load. The PV system generates a power that is dependent on the changing climate conditions: the solar irradiation, the temperatures of the panels and the load change [1]. Thus, a method of searching the maximum point power (MPP) for controlling the duty cycle of DC/DC converter is necessary to ensure optimal operation for PV system under different operating conditions [2]. Several techniques are developed for tracking the maximum point power (MPPT) satisfying the non-linearity of the characteristic of PV modules and the conditions described above, each has their own advantage and disadvantages [3]-[5].

This paper focuses on the comparison of static and dynamique regime of Sliding Mode Controller (SMC) and Fuzzy Logic Controller (FLC) for the tracking of the maximum power point under irradiance change. The efficiency and precision of solar power system are influenced by to the nonlinear variations, thus SMC is designed and compared with FLC for effective operation under non-linear parameters variations [6][10].

The controlled developed helps to avoid the drawback of the FLC, in this method the system state is confined on the sliding surface and is driven to the origin: the sliding surface $d P_{p v} / d I_{p v}$ is selected to ensure that the system state will hit the surface and produce maximum power output persistently, to avoid saturation of proposed control the scaling constant $\mathrm{k}$ is used, its value must not be large and it can be determined by $k \leq 1 /|S|_{\max }$ 
On the other hand, for the connecting of these systems to the electricity distribution network we use inverters, which the profitability is a key element influencing energy supplied, quality and performance of the installation. The structure of the multilevel inverter allows responding in these requirements by increasing power and reducing harmonics of AC load. Currently, the multi-level inverters are increasingly used in applications for renewable energy [11]-[13].

\section{PV SYSTEM}

A photovoltaic cell is made of semi-conductor materials and converts light energy directly into electrical energy. It is based on physical phenomenon called photovoltaic effect. To produce more power, the solar cell is assembled to form a module. The serial connections of several cells increase the voltage, while the implementation in parallel increase the current.

Several models of cells exist, the model used in this paper is shown in Figure 1. Because of its simplicity, this empirical model is currently the more commonly used. It is made of a constant current source modelling the magnetic flux where Ipv is photocurrent create by radiation from sun and of diode, which represents a $P-N$ junction of the cell, the losses are modelled by two resistors: a shunt resistance and a series resistance [14], [15].

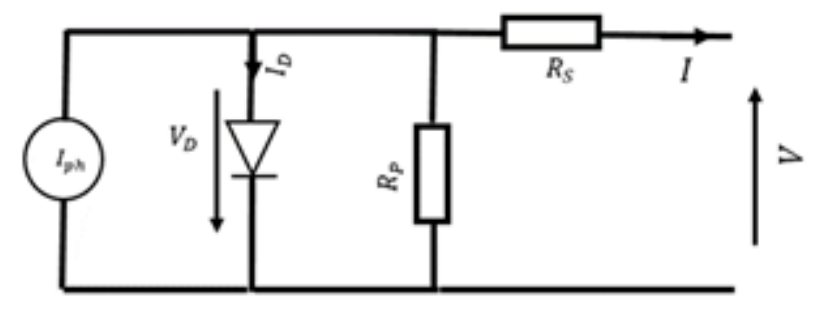

Figure 1. Equivalent circuit of the PV cell

\section{MPPT CONTROL}

The operating power of generators is calculated from the voltage current product. However, the determination of the reference power is more delicate because it is a function of meteorological parameters (temperature, irradiance). The operating at maximum power point is difficult to achieve because this reference is variable and characterized by a nonlinear function. Several techniques are developed to provide the optimal aerating [16], [17]. Figure 2 shows the PV array characteristic curve with the maximum point power variation under different irradiation $\left(400 \rightarrow 600 \rightarrow 800 \rightarrow 1000 \mathrm{~W} / \mathrm{m}^{2}\right)$.

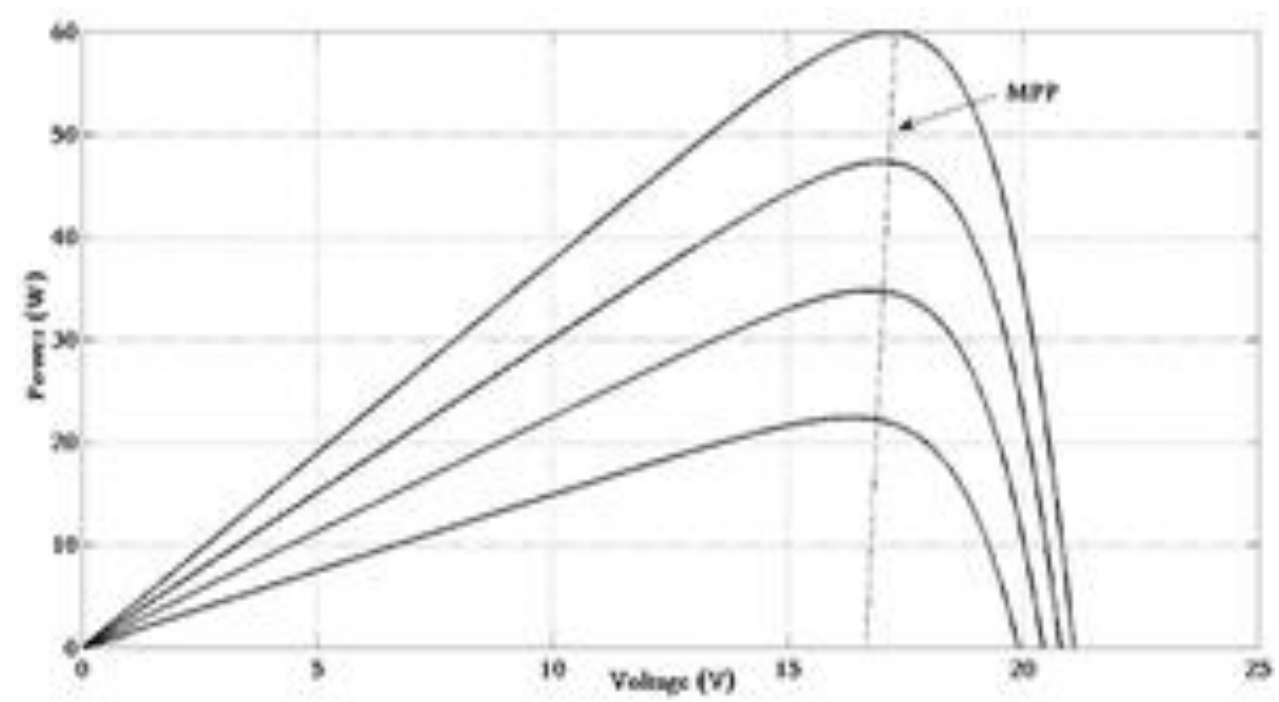

Figure 2. Maximum power point under different irradiation 


\subsection{DC/DC Converter (Boost Converter)}

This DC/DC converter also called boost converter is a static electronic power converter device thereby increasing the initial continuous voltage, it makes to impose the current determined by MPPT algorithm. The system including the boost converter consist of two operating sequence, the first sequence shown in Figure 3 is characterized by a closed switch $(S=1)$ and the diode is open.

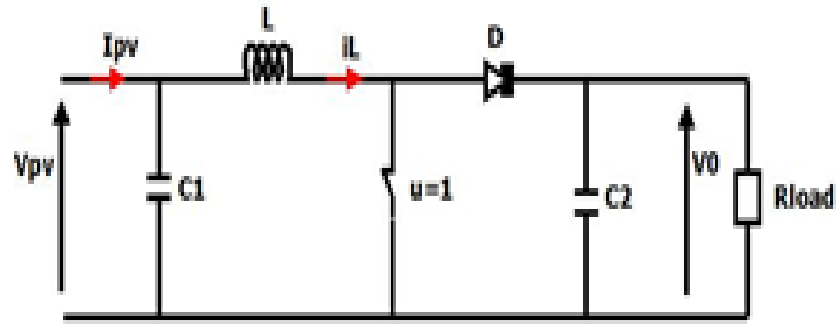

Figure 3. Boost converter in the first sequence

In this case, the equations describing the system are:

$$
\left\{\begin{array}{l}
\frac{d i_{L}}{d t}=\frac{V_{p v}}{L} \\
\frac{d V_{0}}{d t}=-\frac{V_{0}}{R C_{2}}
\end{array}\right.
$$
in Figure 4.

An open switch characterizes the second sequence and the diode is closed. This sequence is shown

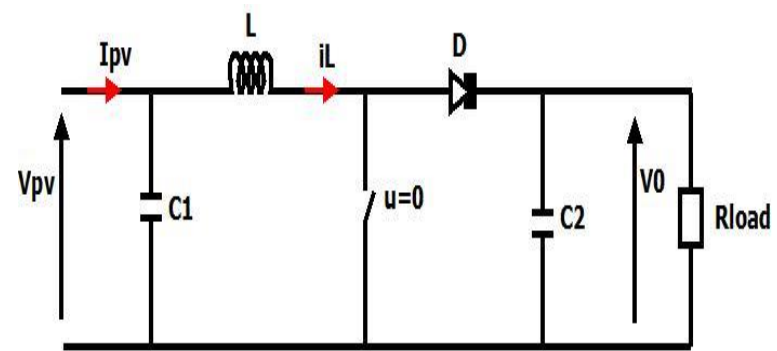

Figure 4. Boost converter in the second sequenc

In this case, the equations describing the system are:

$$
\left\{\begin{array}{l}
\frac{d i_{L}}{d t}=\frac{V_{p v}-V_{0}}{L} \\
\frac{d V_{0}}{d t}=-\frac{V_{0}}{R C_{2}}+\frac{i_{L}}{C_{2}}
\end{array}\right.
$$

From two systems of equations $(6,7)$, the model mathematic of the boost converter is given by [18]: 


$$
\left\{\begin{array}{l}
\frac{d i_{L}}{d t}=\frac{V_{p v}-V_{0}}{L}+\frac{V_{0}}{L} u \\
\frac{d V_{0}}{d t}=-\frac{V_{0}}{R C_{2}}+\frac{i_{L}}{C_{2}}-\frac{i_{L}}{C_{2}} u
\end{array}\right.
$$

Where is the state of the switch $u$. Equations 3 can be described by:

$\dot{x}=f(x, t)+g(x, t) \mathrm{u}+A$

Where:

$$
\begin{gathered}
x=\left[\begin{array}{ll}
x_{1} & x_{2}
\end{array}\right]^{T_{r}}=\left[\begin{array}{ll}
i_{L} & V_{0}
\end{array}\right]^{T_{r}} \\
f(x)=\left[\begin{array}{cc}
0 & \frac{-x_{2}}{L} \\
\frac{x_{1}}{C_{2}} & \frac{-x_{2}}{R C_{2}}
\end{array}\right] ; g(x)=\left[\begin{array}{c}
\frac{x_{2}}{L} \\
\frac{-x_{1}}{C_{2}}
\end{array}\right] ; A=\left[\begin{array}{c}
\frac{V_{p v}}{L} \\
0
\end{array}\right]
\end{gathered}
$$

\subsection{Sliding Mode Control}

The sliding mode control is a nonlinear control, it is characterized by the discontinuity of the control

in passage by switching surface called: sliding surface [19], [20].
Choice of sliding surface: the condition of maximum power point PPM is given by $\frac{d P_{P V}}{d V_{P V}}=0$

In this condition, it is guaranteed that the system state will hit the surface and produce maximum power output persistently.

$$
S(x)=\frac{d P_{P V}}{d V_{P V}}=I_{P V}+\frac{d I_{P V}}{d V_{P V}} V_{P V}
$$

Calculation of the equivalent control, it is determined from the flowing condition:

$$
\dot{S}(x)=\frac{\partial S}{\partial x_{1}} \dot{x}_{1}+\frac{\partial S}{\partial x_{2}} \dot{x}_{2}
$$

Knowing that the surface $S$ depends on $i_{L}$ then we can write:

$$
\begin{aligned}
& \frac{\partial S}{\partial x_{1}} \neq 0 \quad ; \quad \frac{\partial S}{\partial x_{2}}=0 \\
& \dot{S}(x)=\frac{\partial S}{\partial x_{1}} \cdot \dot{x}_{1}=0
\end{aligned}
$$

Then, the expression of equivalent control can be derived from the condition $\mathrm{x} 1=0$

$$
u_{\mathrm{eq}}=1-\frac{V_{P V}}{V_{0}}
$$

Finally, the real control signal is given by: 


$$
u= \begin{cases}1 & u_{e q}+k S \geq 1 \\ u_{e q}+k S, \text { for } & 0<u_{e q}+k S<1 \\ 0 & u_{e q}+k S \leq 0\end{cases}
$$

Where $k$ is positive scaling constant, the equivalent control is comprised with $u_{e q}$ and $k S$, where $u_{e q}$ is the required effort for $\dot{S}$ and $k S$ can be considered as the effort to track the MPP. The surface sliding and duty cycle versus operation region are shown in Figure 5.

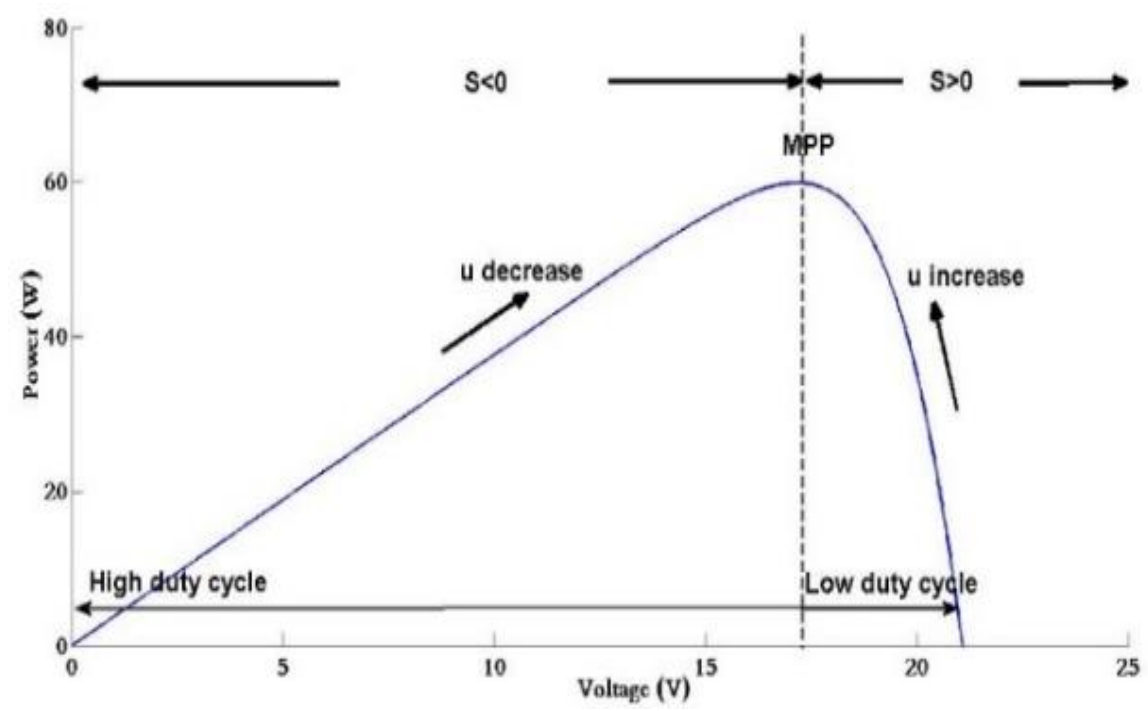

Figure 5. Duty cycle versus operation region

A Lyapunov function is defined as:

$V=\frac{1}{2} S^{2}$

Knowing that:

$I_{p v}=N_{p} I_{s c}-N_{p} I_{s c} \exp \left(\frac{V_{p v}-N_{s} V_{o c}}{n_{s} v_{t}}\right)$

And

$\frac{d I_{p v}}{d V_{p v}}=-\frac{N_{p} I_{s c}}{n_{s} v_{t}} \exp \left(\frac{V_{p v}-N_{s} V_{o c}}{n_{s} v_{t}}\right)$

Substituting (14) and (15) into (7), the sliding surface can be written:

$$
S(x)=N_{p} \mathrm{I}_{s c}-\left(N_{p} I_{s c}+\frac{N_{p} I_{s c}}{n_{s} v_{t}} V_{p v}\right) \exp \left(\frac{V_{p v}-N_{s} V_{o c}}{n_{s} v_{t}}\right)
$$

The time derivative of $\mathrm{S}$ can be written as: 
$\dot{S}(x)=-\left(2+\frac{V_{p v}}{n_{s} v_{t}}\right) \frac{N_{p} I_{s c}}{n_{s} v_{t}} \exp \left(\frac{V_{p v}-N_{s} V_{o c}}{n_{s} v_{t}}\right) \frac{d V_{p v}}{d t}$

1. Case $S(x)>0$ :

In this case, the voltage must be decreased to reach the PPM, it means that $\frac{d V_{p v}}{d t}>0$, by replacing equation (17), we get $S>0$, which means $S(x) S(x)<0$. It is concluded that the sliding mode is provided.

2. Case $S(x)>0$ :

In this case, the voltage must be decreased to reach the PPM, it means that $\frac{d V_{p v}}{d t}<0$ by replacing
equation (17), we get $\dot{S}>0$, which means $\dot{S}(x) \mathrm{S}(x)<0$. It is concluded that the sliding mode is provided.

\subsection{Fuzzy Logic Controller}

The fuzzy logic controller is advantageously a robust control, which does not require the exact knowledge of the mathematical model of the system. This command is better adapted to the nonlinear systems [21], [23].

Figure 6 shows the proposed structure of fuzzy logic controller; it consists of two input (E, CE) and one output (Duty cycle), the relation between the input an output is given by following equations.

$$
\begin{aligned}
& E_{(n)}=\frac{P_{(n)}-P_{(n-1)}}{V_{(n)}-V_{(n-1)}} \\
& C E_{(n)}=E_{(n)}-E_{(n-1)} \\
& C \longrightarrow \text { Fuzzifier } \longrightarrow \text { Rule base } \longrightarrow \text { Defuzzifier } \longrightarrow D
\end{aligned}
$$

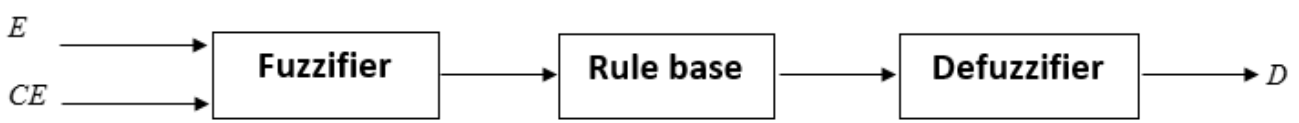

Figure 6. Fuzzy controller diagram

FIS consists of Fuzzy Inference System (FIS) Editor, Membership Function Editor, Rule Editor, and Rule Viewer, Surface Viewer and defuzzification. The decision rule table relating to the input to the output fuzzy sets as shown in Table 1.

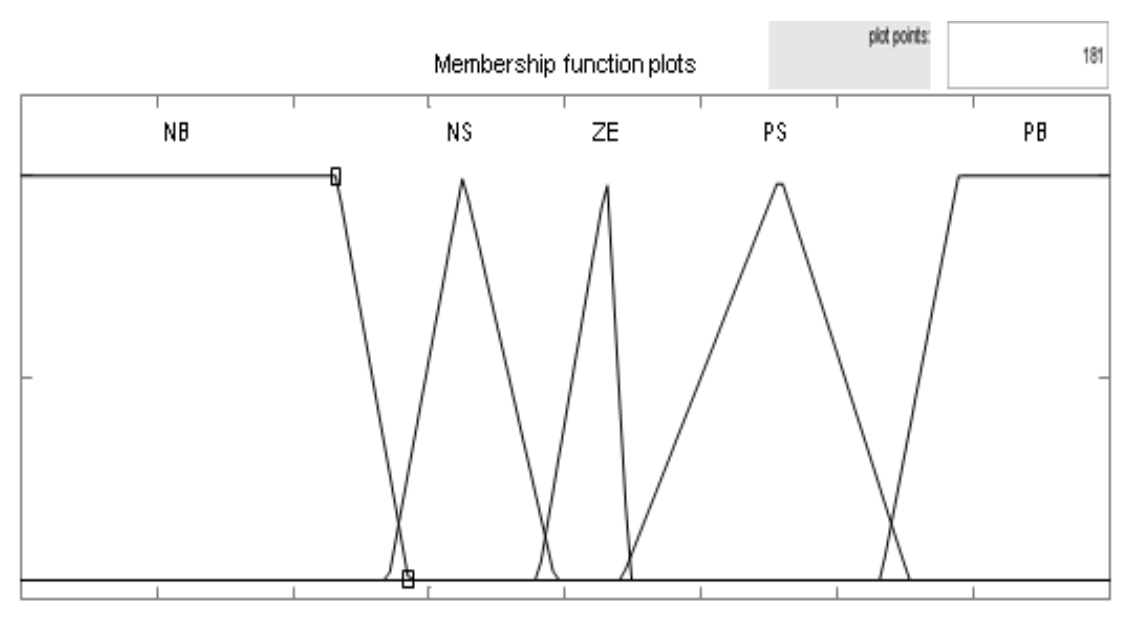

Figure 7. Membership function for inputs and output of fuzzy controller 
Table 1. Fuzzy Rule base tables

\begin{tabular}{cccccc}
\hline E/CE & NB & NS & ZE & PS & PB \\
\hline NB & ZE & ZE & NB & NB & NB \\
NS & ZE & ZE & NS & NS & NS \\
ZE & NS & ZE & ZE & ZE & PS \\
PS & PS & PS & PS & ZE & ZE \\
PB & PB & PB & PB & ZE & ZE \\
\hline
\end{tabular}

\section{DC/AC STATIC CONVERTER}

The voltage extracted from the PV generator is the DC voltage, to connect a three-phase load it is necessary to use the DC/AC converter. To meet the above requirement, the Neutral Point Clamped (NPC) three level inverter is used in this work. Figure 8 shows the neutral point clamped (NPC) three-level inverter.

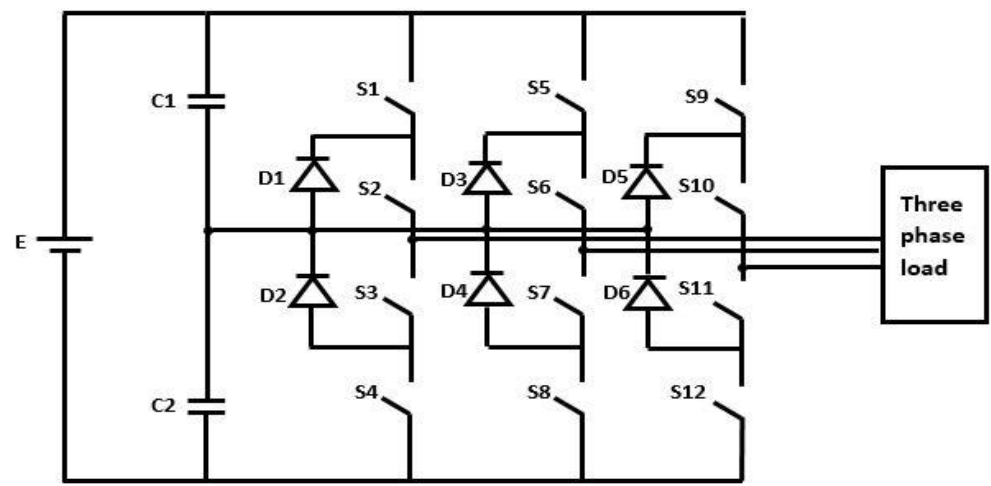

Figure 8. NPC three level inverter

To generate the command impulses, two commands are used and evaluated:

1. PDWM (Phase Disposition PWM):

To generate the command impulses of converter an $\mathrm{N}$ voltage levels, N-1 triangular carriers are necessary. These carriers have the same frequency $f_{c}$ and the same amplitude $A_{c}$ the carriers can be shifted horizontally, the phase difference between two consecutive signals is given by $2 / N-1$, the carriers have the same shifted vertical. They are then compared with a reference signal of amplitude $A_{r}$ and frequency $f_{\dot{r}}$

The Amplitude modulation index $m_{a}$ is given by:

$$
m_{a}=\frac{2 A r}{(N-1) A_{c}}
$$

The frequency modulation index $m_{f}$ is given by:

$$
m_{f}=\frac{f_{c}}{f_{m}}
$$

In this case all carriers are identical in amplitude $A_{C}$, in phase and in frequency $F_{C}$.

\section{SVPWM (Space Vector PWM):}

This is an advanced PWM method because of its superior performance characteristics, it has been finding widespread applications in recent years [23], [24]. The SVPWM algorithm consist of five steps:
a. Determination of the voltage reference vector.
b. Calculation of the sector.
c. Calculation of the region.
d. Calculation of the switching time.
e. Calculation of the switching sequences. 
With $\alpha \beta$ transformation the signal is demonstrated in a two-dimensional plane, the three-voltage vectors are replaced with $V_{\alpha}$ and $V_{\beta}$ :

$$
\left[\begin{array}{l}
V_{\alpha} \\
V_{\beta}
\end{array}\right]=\frac{2}{3}\left[\begin{array}{ccc}
1 & -\frac{1}{2} & -\frac{1}{2} \\
0 & \frac{\sqrt{3}}{2} & -\frac{\sqrt{3}}{2}
\end{array}\right]\left[\begin{array}{l}
V_{a n} \\
V_{b n} \\
V_{c n}
\end{array}\right]
$$

Where:

$V_{a n}=V_{m} \times \sin (\omega \mathrm{t})$

$V_{b n}=V_{m} \times \sin \left(\omega \mathrm{t}-2 \frac{\pi}{3}\right)$

$V_{c n}=V_{m} \times \sin \left(\omega \mathrm{t}-4 \frac{\pi}{3}\right)$

The amplitude and angle of the reference vector are given by:

$$
V_{r e f}=\sqrt{(V \alpha)^{2}+\left(V_{\beta}\right)^{2}} ; \theta=\tan ^{-1}\left(\frac{V_{\beta}}{V_{\alpha}}\right)
$$

The vector diagram of a three-level inverter is shown in Figure 9, it can be subdivided into six sectors (I to VI).

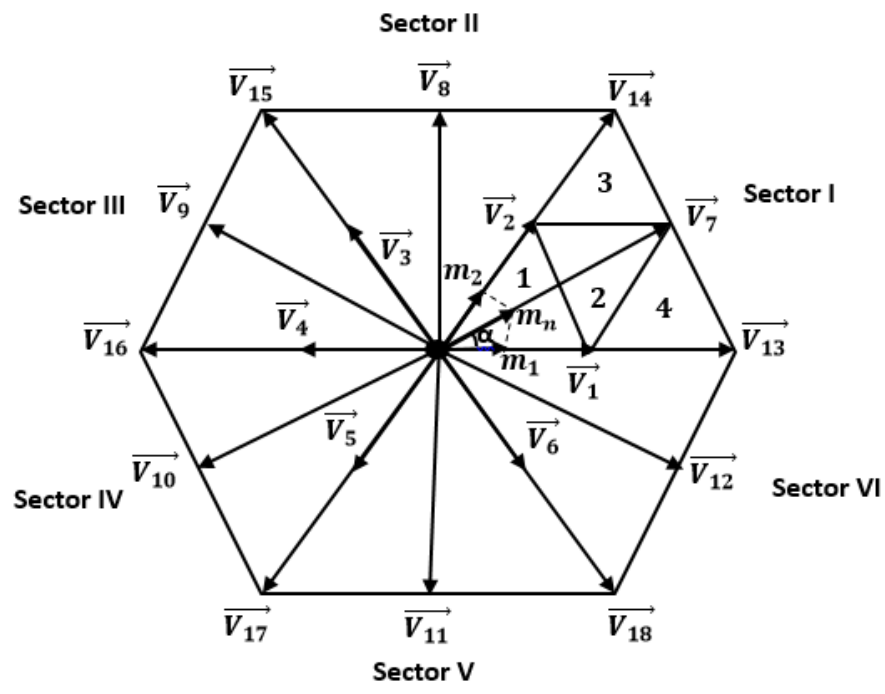

Figure 9. Vector diagram for three level inverter

According to the value of equation (24), the sectors can be determined by: 
Sector $= \begin{cases}1 \quad \text { if } \quad 0<\theta<\frac{\pi}{3} \\ 2 \quad \text { if } \frac{\pi}{3}<\theta<\frac{2 \pi}{3} \\ 3 \quad \text { if } \frac{2 \pi}{3}<\theta<\pi \\ 4 \quad \text { if } \pi<\theta<\frac{4 \pi}{3} \\ 5 \quad \text { if } \frac{4 \pi}{3}<\theta<\frac{5 \pi}{3} \\ 6 \quad \text { if } \frac{5 \pi}{3}<\theta<0\end{cases}$

From Figure 8, the region may be determined, according to the following conditions:

$$
\text { Region }=\left\{\begin{array}{l}
1 \text { if } \mathrm{m}_{1}<0.5 \text { and } \mathrm{m}_{2}<0.5 \text { and } \mathrm{m}_{1}+\mathrm{m}_{2}<0.5 \\
2 \text { if } \mathrm{m}_{1}<0.5 \text { and } \mathrm{m}_{2}<0.5 \text { and } \mathrm{m}_{1}+\mathrm{m}_{2}>0.5 \\
3 \text { if } \mathrm{m}_{2}>0.5 \\
4 \text { if } \mathrm{m}_{1}>0.5
\end{array}\right.
$$

Where

$$
\begin{aligned}
& m_{1}=m_{n} \frac{2}{\sqrt{3}} \sin \left(\frac{\pi}{3}-\alpha\right) \\
& m_{2}=m_{n} \frac{2}{\sqrt{3}} \sin (\alpha) \\
& m_{n}=\frac{V_{r e f}}{\frac{2 U_{D C}}{3}}
\end{aligned}
$$

The reference vector in sector I and region 2 is shown in Figure 10.

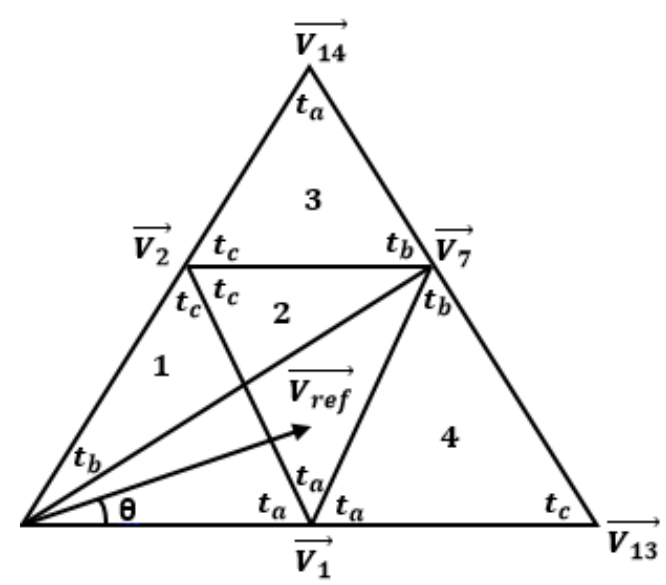

Figure 10. Reference voltage in the sector I 
$\vec{V}_{r e f} \mathrm{~T}_{s}={\overrightarrow{V_{1}}}_{a}+{\overrightarrow{V_{7}}}_{b}+{\overrightarrow{V_{2}}}_{c}$

Where :

$$
\left\{\begin{array}{l}
\overrightarrow{V_{1}}=\frac{U_{D C}}{3} e^{j 0} \\
\overrightarrow{V_{2}}=\frac{U_{D C}}{3} e^{j \frac{\pi}{3}} \\
\overrightarrow{V_{7}}=\frac{U_{D C}}{\sqrt{3}} e^{j \frac{\pi}{6}}
\end{array}\right.
$$

Substituting (29) and (31) into (30), we can write:

$$
m_{n} T_{s}[\cos (\theta)+j \sin (\theta)]=\frac{1}{2} t_{a}+\frac{\sqrt{3}}{2}\left[\cos \left(\frac{\pi}{6}\right)+j \sin \left(\frac{\pi}{6}\right)\right] t_{b}+\frac{1}{2}\left[\cos \left(\frac{\pi}{3}\right)+j \sin \left(\frac{\pi}{3}\right)\right] t_{c}
$$

Knowing that:

$$
T_{S}=t_{a}+t_{b}+t_{c}
$$

The switching time in the sector I and region 2 can be written:

$$
\left\{\begin{array}{l}
t_{a}=T_{s}-\frac{4}{\sqrt{3}} m_{n} T_{s} \sin \theta \\
t_{b}=-T_{s}+\frac{4}{\sqrt{3}} m_{n} T_{s} \sin \left(\frac{\pi}{3}+\theta\right) \\
t_{c}=T_{s}-\frac{4}{\sqrt{3}} m_{n} T_{s} \sin \left(\frac{\pi}{3}-\theta\right)
\end{array}\right.
$$

The switching sequences in the sector I and region 2 is defined by:

$$
\begin{array}{ll}
-S_{1}=\frac{T_{c}}{4}+\frac{T_{a}}{4}+\frac{T_{b}}{2} & -S_{5}=\frac{T_{c}}{4} \\
-S_{2}=\frac{T_{s}}{2} & -\mathrm{S}_{6}=\frac{T_{s}}{2}-\frac{T_{a}}{4}
\end{array}
$$

\section{SIMULATION RESULT}

To evaluate the performance and robustness of the system were developed a comparative study based on simulation in Matlab/Simulink between sliding mode and perturb\&observe controllers. The proposed system including the three-phase three-level inverter shown in Figure 11, the proposed MPPT nonlinear controller is evaluated by varying the irradiance.

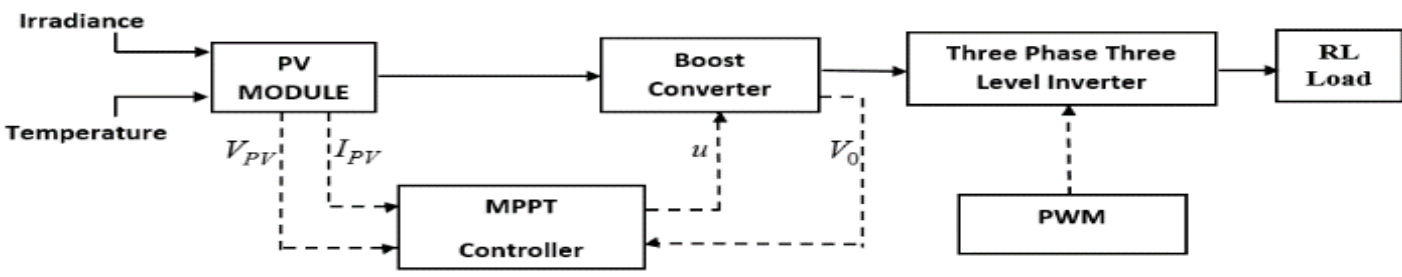

Figure 11. System topology 
The output power and voltage of the boost converter obtained by using FLC and sliding mode are shown in Figure 12 and Figure 13. It is observed that both SMC and FLC can track the MPP, we can also confirm that the SMC provides better reponse time, omproved transient behavior.

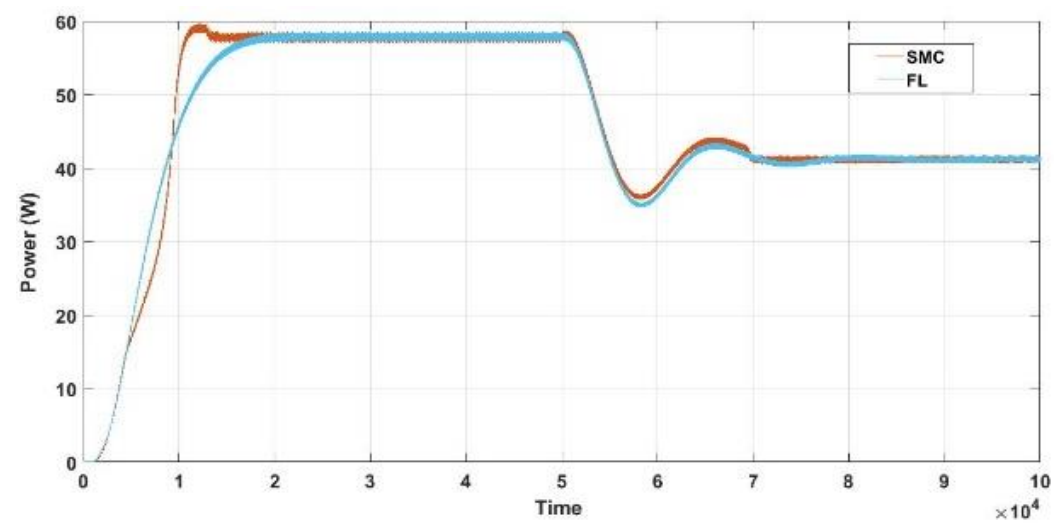

Figure 12. Output power for FLC and SMC

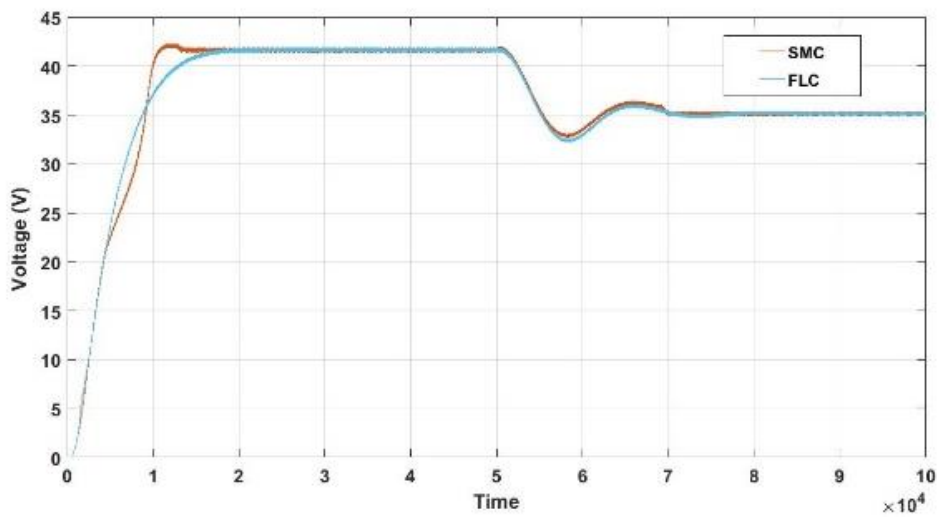

Figure 13. Output voltage for FLC and SMC

About DC/AC conversion, the output three level inverter is shown in Figure 14 and Figure 15. We note that the three-level voltage remains stable and has a desired value in sliding mode controller. The harmonic analysis of output three level voltage is shown in table 2 and table 3, the SPWM generates less Total Harmonic Distortion (THD) and higher output quality. Based on obtained results, the SVPWM technique remains the more reliable solution. 


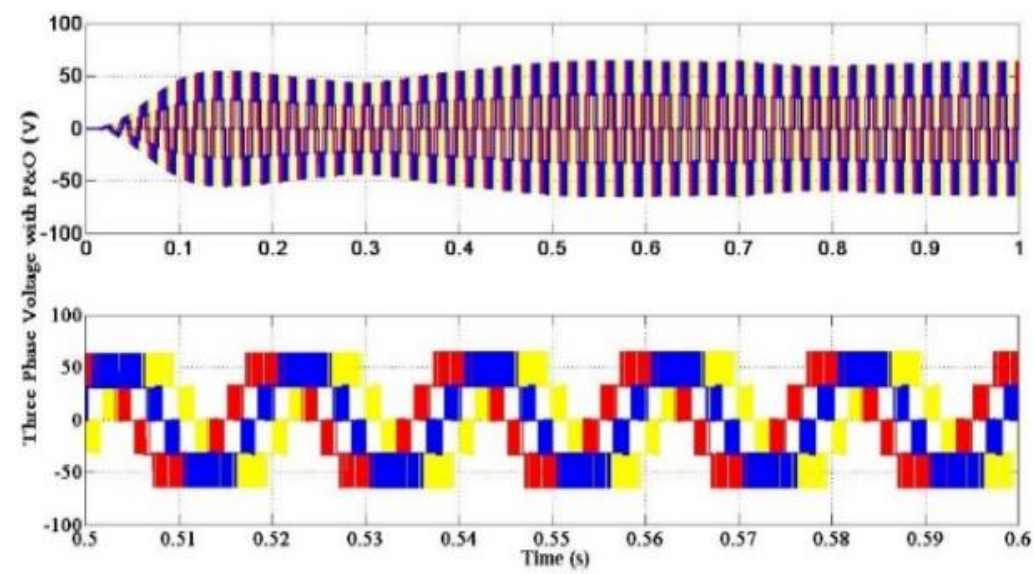

Figure 14. Three phase voltage with FLC

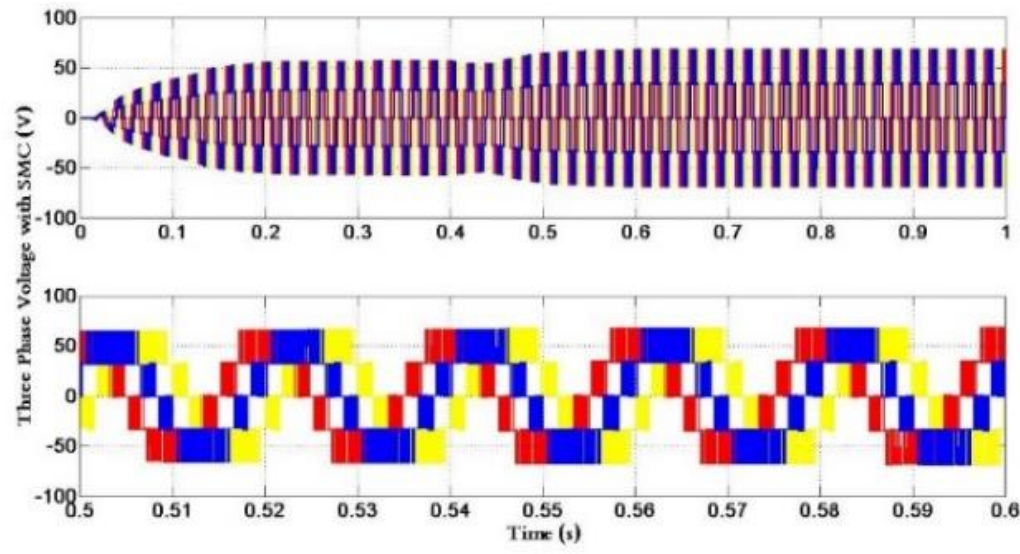

Figure 15. Three phase voltage with sliding mode

Table 2. $V_{R M S}$ (fundamental) for different modulation indices

\begin{tabular}{cccc}
\hline ma & 1 & 0.9 & 0.8 \\
\hline SVPWM & 39.31 & 39.21 & 38.75 \\
PDPWM & 38.47 & 37.92 & 37.26 \\
\hline
\end{tabular}

Table 3. \% THD (voltage) for Different Modulation Indices

\begin{tabular}{cccc}
\hline ma & 1 & 0.9 & 0.8 \\
\hline SVPWM & 22.16 & 25.61 & 33.04 \\
PDPWM & 30.45 & 32.67 & 34.43 \\
\hline
\end{tabular}

\section{CONCLUSION}

In this paper, fuzzy logic controller and sliding mode controller have been designed and simulated for the proposed PV system, comparison for simulation results have been presented for the same environmental conditions.

The maximum power point (MPP) to be achieved through the too controller, sliding mode has proved a satisfactory behavior: the stability is easily achieved, and guaranteed during irradiance change, the SMC shows a better performance in transitional and permanent regime.

The NPC three level is used for the DC/AC conversion, two commands have been developed and tested for different modulation indices ranging from 0.8-1. Compared to Phase Disposition Pulse Width Modulation (PDPWM), the Space Vector Pulse Width Modulation (SVPWM) has showed superior performances due to better quality reached of output voltage for all modulation indexes. 


\section{APPENDIX}

Table 4. PV Module Parameter

\begin{tabular}{cc}
\hline Temperature (T) & $25^{\circ} \mathrm{C}$ \\
\hline Maximum power (Pmax) & $60 \mathrm{~W}$ \\
Voltage at Pmax (Vmp) & $17.1 \mathrm{~V}$ \\
Current at Pmax (Imp) & $3.5 \mathrm{~A}$ \\
Short-circuit current (Isc) & $3.8 \mathrm{~A}$ \\
Open-circuit voltage (Voc) & $21.1 \mathrm{~V}$ \\
\hline
\end{tabular}

Table 5. Boost Converter Parameters

$\begin{array}{cc}\text { Inductance (L) } & 25^{\circ} \mathrm{C} \\ \text { Capacitance (C) } & 60 \mathrm{~W} \\ \text { switching frequency (fc) } & 17.1 \mathrm{~V}\end{array}$

Table 6. Three Level Inverter Parameters

\begin{tabular}{cc}
\hline Capacitance $(\mathrm{C} 1)$ & $190010^{-3} \mathrm{~F}$ \\
\hline Carrier switching frequency (fc) & $6 \mathrm{KHZ}$ \\
Resistance load (R) & $30 \Omega$ \\
Inductance (L) & $5010^{+3} \mathrm{H}$ \\
\hline
\end{tabular}

\section{NOMENCLATURE}

$I_{P V}=$ Photo-current

$I_{0}=$ Reverse saturation current

$I=$ Short circuit current

$I_{d}^{s c}=$ Diode Current

$I=$ Output current of solar cell

$I_{M M P}=$ Current at maximum power point

$I_{L}=$ Coil current for inductor

$K=$ Boltzmann's constant

$R_{s}=$ Series resistance

$R_{P=\text { Shunt resistance }}$

$V=$ Output voltage of solar cell

$V_{O C}=$ Open circuit voltage

$V_{T}=$ Thermal voltage

$V_{M M P}^{T}=$ Voltage at maximum power point
$A_{C}=$ Carrier amplitude

$A_{r}=$ Reference amplitude

$F=$ Carrier frequency

$F_{r}=$ Reference amplitude

$m_{a}^{r}=$ Amplitude modulation

$m_{f}=$ Frequency modulation

FLC $=$ Fuzzy logic controller

$\mathrm{SMC}=$ Sliding mode controller

$\mathrm{NPC}=$ Neutral point clamped

$V_{0}=$ Output voltage of boost converter

$u=$ State of the switch

MPP=Maximum Power Point

MPPT=Maximum Power Point Tracking

\section{REFERENCES}

[1] M. Hosenuzzaman, N. A. Rahim, J. Selvaraj, M. Hasanuzzaman, "Factors affecting the PV based power generation," 3rd IET International Conference on Clean Energy and Technology (CEAT), pp. 1-6, 2014.

[2] A. P. Bhatnagar, B. R. K. Nema, "Conventional and global maximum power point tracking techniques in photovoltaic applications: A review J.” Renew. Sustainable Energy 5, 032701, pp. 1-23, 2013.

[3] A. Bouchakour, A. Borni, H.M. Idriss, L. Zaghba, F. Amor, M. Brahami, "A comparative and analytical study of various MPPT techniques applied in PV systems for fast changing environmental conditions," 3rd International Renewable and Sustainable Energy Conference (IRSEC), pp. 1-6, 2015.

[4] X. Li, H. Wen, Y. Hu, "Evaluation of different maximum power point tracking (MPPT) techniques based on practical meteorological data," IEEE International Conference on Renewable Energy Research and Applications (ICRERA), pp:696-701, 2016

[5] S. Kalika, L. Rajaji, S. Gupta, "Designing and implementation of MPPT controller for varying radiance in solar PV system," IET Chennai 3rd International on Sustainable Energy and Intelligent Systems (SEISCON), pp: 1 - 5, 2012.

[6] R. Praveen, K. Latha, “Comparison of various MPPT techniques for different fuel flow," International Conference on Energy Efficient Technologies for Sustainability, pp: 540 - 545, 2013.

[7] X. Weng, Z. M. Zhao, F. B. He, L. Q. Yuan, T. Lu, "Comparison of several MPPT methods for PV arrays under partially shaded conditions," International Conference on Renewable Power Generation (RPG), pp: 1 - 6, 2015.

[8] M.A. Abdourraziq and M. Maarouf, "Experimental Verification of the Main MPPT Techniques for Photovoltaic System,” International Journal of Power Electronics and Drive Systems, vol.8, pp: 384-391, 2017. 
[9] F.R. Islam, K. Prakash, K. A. Mamun, A. Lallu, R. Mudliar, "Design a Optimum MPPT Controller for Solar Energy System" Indonesian Journal of Electrical Engineering and Computer Science (IJEECS), Vol. 2, No. 3, pp. $545 \sim 553$, June 2016

[10] S. Selvan, P. Nair, U. Umayal, "A Review on Photo Voltaic MPPT Algorithms" International Journal of Electrical and Computer Engineering (IJECE), Vol 6, No 2, pp. 567 582, April 2016.

[11] Ouadi, H., Et-taoussi, M., Bouhlal, A., "Nonlinear Control of Multilevel Inverter for Grid Connected Photovoltaic System with Power Quality Improvement," International Review of Electrical Engineering (IREE),12 (1), pp. 43 59, 2017.

[12] O. Salama; A. Tabyaoui; M. Benchagra., "Analysis and comparison of Control on Power Converters in Photovoltaic Energy," IEEE Conference on Electrical and Information Technologies (ICEIT), Morocco 15-18 November 2017.

[13] A. Alexander; M. Thathan, "Modelling and analysis of modular multilevel converter for solar photovoltaic applications to improve power quality," IET Renewable Power Generation, vol.9 (issue:1), pp. 78 - 88, 2015.

[14] S. Shongwe; M. Hanif, "Comparative Analysis of Different Single-Diode PV Modeling Methods," IEEE Journal of Photovoltaics, vol.5 (issue:3), pp: 938 - 946, 2015.

[15] Y. Mahmoud; W. Xiao; H. H. Zeineldin," A Simple Approach to Modeling and Simulation of Photovoltaic Modules," IEEE Transactions on Sustainable Energy, vol.3 (issue:1), pp: 185 - 186, 2012.

[16] D. Sera, L. Mathe, T. Kerekes, S.V. Spataru, R. Teodorescu," On the Perturb-and-Observe and Incremental Conductance MPPT Methods for PV Systems," IEEE Journal of Photovoltaics, vol:3, Nº3, pp:1070-1078, 2013.

[17] R.M. Linus, P. Damodharan, "Maximum power point tracking method using a modified perturb and observe algorithm for grid connected wind energy conversion systems," IET Renewable Power Generation, vol:9 (issue:6), pp:682-289, 2015.

[18] R. Keshri, M. Bertoluzzo, G. Buja, "Integration of a Photovoltaic panel with an electric city car," Electric Power Components and Systems, vol.42 (issue:5), pp: 481-495, 2014.

[19] N. Ghaffarzadeh; S. Bijani, "Dual surface sliding mode controller for photovoltaic systems enhanced by a ripple domain search maximum power point tracking algorithm for fast changing environmental conditions," IET Renewable Power Generation, vol.10 (issue:5), pp: 611 - 622, 2016.

[20] E. Mamarelis, G. Petrone, G. Spagnuolo, "Design of a sliding-mode-controlled SEPIC for PV MPPT applications," IEEE Transactions on Industrial Electronics, vol.61 (issue:7), pp: 3387 - 3398, 2014.

[21] Chandani Sharma, Anamika Jain, "Performance Comparison of PID and Fuzzy Controllers in Distributed MPPT", International Journal of Power Electronics and Drive System (IJPEDS), Vol. 6, No. 3, September 2015, pp. 625635 ISSN: 2088-8694.

[22] Mounir Derri, Mostafa Bouzi, Ismail Lagrat, Youssef Baba, Murtaza. "Fuzzy Sliding Mode Control for Photovoltaic System". International Journal of Power Electronics and Drive Systems(IJPEDS), Vol. 7, No 3, pp. 964-973, Septembre 2016.

[23] A. Rahiman Beig, S. Kanukollu, K. Al Hosani, A. Dekka, "Space-Vector-Based Synchronized Three-Level Discontinuous PWM for Medium-Voltage High-Power VSI," IEEE Transactions on Industrial Electronics, Volume: 61 (Issue: 8), pp: 3891 - 3901, 2014.

[24] H. Hu, W. Yao, Z. Lu, "Design and Implementation of Three-Level Space Vector PWM IP Core for FPGAs," IEEE Transactions on Power Electronics, Volume: 22 (Issue: 6), pp. 2234 - 2244, 2007.

\section{BIOGRAPHIES OF AUTHORS}

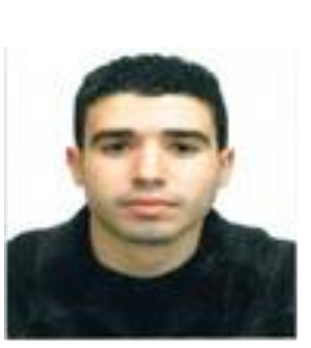

Othmane Salama, was born in Khouribga, Morocco, in 1987. He received the Master degrees, in Electrical Engineering from the Faculty of Sciences and Techniques, Fez. He pursues his doctoral program at at the Faculty of Sciences and Techniques, Hassan 1st university. His research interests are automatic control, power electronics and renewable energy.

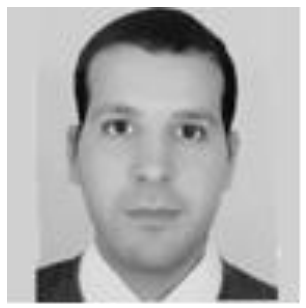

Mohamed Benchagra, was born in Beni-Mellal, Morocco, in 1982. He received the $\mathrm{Ph}$. D degrees, in Electrical Engineering from Ecole Mohammadia d'Ingénieurs, Université MohamedV, Rabat, Morocco, in 2013. He is currently an Assistant Professor at National School of Application Sciences (ENSA Khouribga) Hassan 1er University, Morocco. His research interests are electric machines, power electronics, power systems and renewable energy. Dr. Benchagra is a member of the IEEE. 
Abdelmoumen Tabyaoui, was born in Errachidia, Morocco, in 15/04/1965.

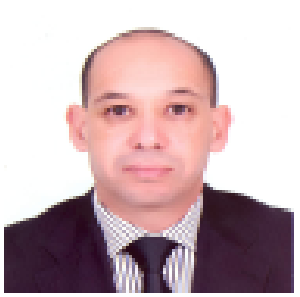

He obtained his Phd in Molecular Physics from Burgundy university, Dijon France, 101992 and a Doctorate thesis in Physical Sciences from the Mohamed Vth university of Rabat, Morocco, in 2005. Dr Tabyaoui, professor at the Faculty of Sciences and Techniques, Hassan 1st university, is currently working as a Deputy Director of the National School of Applied Sciences of Khouribga, Hassan 1st university, Settat, Morocco.

His research area includes atomic and molecular physics. 